Journal of the Operations Research

Society of Japan

Vol. 22, No. 4, December 1979

\title{
THE EFFICIENCY OF TWO-STAGE SERIES LINES
}

\author{
Toshirou Iyama \\ Iwate University
}

(Received September 29, 1978; Final August 17, 1979)

\begin{abstract}
In this paper, we consider the procedure to estimate the various effects of the design factors in the twostage series lines in which the first stage has an arbitrary service time. First, the system states are represented by the imbedded Markov chain and the steady state probabilities are solved by the Laplace transform with respect to the arbitrary service time distribution. Next, the efficiency, the idling time distribution, the blocking time distribution and the number of in-process works distribution are considered from the system states. Moreover the relations between the dual models are discussed.
\end{abstract}

\section{Introduction}

Many papers have been published concerning the two-stage series lines. Hunt and others estimate the efficiencies and the mean number of in-process works for the lines with exponential or erlang service times by the Markov model [6], [7], [8], [11], [12], [13]. However, most of the papers discuss only the efficiencies for the lines with the arbitrary service times by the approximation methods [1], [3], [10]. On the other hand, the queueing system $M / G / 1$ with a finite waiting room which is related to the dual model considered in this paper is discussed by Hashida and others, and the various results are presented [4], [5].

In this paper we consider the procedure to estimate the effects of the design factors in the two-stage series lines in which the first stage has an arbitrary service time and the second stage has an exponential service time. First, we show that the system states can be represented by the imbedded Markov chain like GI/M/1 or M/G/1 queueing model and that the state probabilities in the steady state condition can be solved by the Laplace transform with respect to the arbitrary service time distribution. And from the state probabilities the efficiency, the idling time distribution, the blocking time distribution and 
the number of in-process works distribution are represented. Moreover, we discuss the relations between the dual models and show that the various properties for the dual model can be represented by the other model.

\section{Model}

The two-stage series line consists of two stages to operate the work and the buffer storage holding in-process works temporarily, as shown in Fig. 2.1.

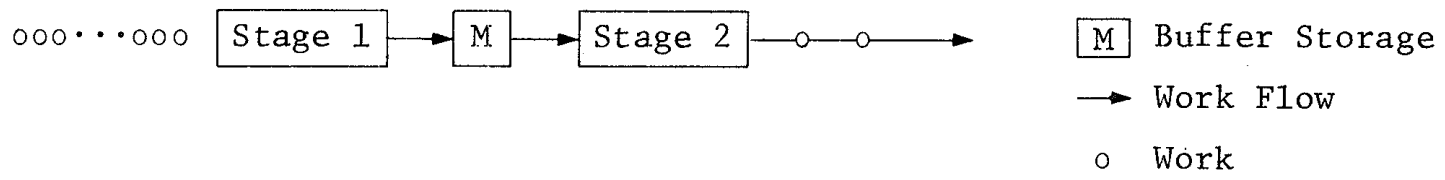

Fig. 2.1 Two-stage series line

Then the line is defined by the service time in stage $i(i=1,2)$ represented by the probability density function (p.d.f.) $f_{i}(x)$ and the buffer capacity $M$.

Assume that there are infinite works ready to be operated in the first stage and there is infinite buffer capacity just behind the second stage, therefore idling due to lack of input works is never occurred in the first stage and blocking is never occurred in the second stage because the completed work is always ejected from the stage. And the service times are mutually independent.

Now we formulate the work flow of this model. This flow is defined by the output interval $0_{i, j}$ between the $(j-1)$-th work and the $j$-th work in stage $i$, which is represented by

$$
0_{i, j}=I_{i, j-1}+x_{i, j}+B_{i, j} \quad(i=1,2 ; j=1,2,3, \ldots)
$$

where $X_{i, j}, I_{i, j-1}$ and $B_{i, j}$ denote the service time for the $j$-th work in stage $i$, the idling time occurred when stage $i$ waits the $j$-th work in stage $i$ after ejecting the (j-1)-th work from the stage and the blocking time occurred when the service for the $j$-th work in stage $i$ is completed but the work finds the buffer full and is held in the stage, respectively. In this equation $I_{i, j-1}$ and $B_{i, j}$ are unknown random variables, but if we have the initial conditions that the numbers of work are independently counted in each stage and that stages 1 and 2 begin to operate the first work at the same time $t=0$ and then there is no inprocess work in the buffer, $i$.e. the $j$-th work in stage 1 is the $(j+1)$-th work in stage 2 and $I_{i, 0}=0, I_{i, j-1}$ and $B_{i, j}$ are given by

$$
I_{2, j-1}=\left[\left(\sum_{n=1}^{j-2} 0_{1, n}+x_{1, j-1}\right)-\sum_{n=1}^{j-1} 0_{2, n}\right]^{+}
$$




$$
\begin{aligned}
& B_{1, j}=\left[\sum_{n=1}^{j-M} 0_{2, n}-\left(\sum_{n=1}^{j-1} 0_{1, n}+x_{1, j}\right)\right]^{+} \\
& I_{1, j-1}=0 \\
& B_{2, j}=0,
\end{aligned}
$$

where the notation $\left[\mathrm{Y}^{+}\right.$denotes

$$
[\mathrm{Y}]^{+}=\operatorname{Max}(0, \mathrm{Y})
$$

and $I_{1, j-1}=B_{2, j}=0$ is given by the above assumption.

3. The imbedded Markov chain

We consider the system states at the time $t=\sum_{n=1}^{j-1} 0_{1, n}+x_{1, j}-0$, i.e. the time just before the completion of service for the $j$-th work in stage 1 . These states are defined by the state of the each stage and the number of in-process works in the buffer and are represented as follows;

$$
\begin{aligned}
& \mathrm{S}_{j}\left(\mathrm{~W}_{1}, \mathrm{~W}_{2} \mid \mathrm{m}\right): \begin{array}{l}
\text { Stages } 1 \text { and } 2 \text { are in operating and } \mathrm{m} \text { in-process works } \\
\text { are in the buffer }(0 \leqq \mathrm{~m} \leqq M)
\end{array} \\
& \mathrm{S}_{j}\left(\mathrm{~W}_{1}, \mathrm{I}_{2} \mid 0\right): \begin{array}{l}
\text { Stage } 1 \text { is in operating and Stage } 2 \text { is in idling and } \\
\text { there is no in-process work in the buffer. }
\end{array}
\end{aligned}
$$

Furthermore the time in which the each state is occurred is given by the following range of time. The state $\mathrm{S}_{j}\left(\mathrm{~W}_{1}, \mathrm{I}_{2} \mid 0\right)$ is occurred in

$$
\mathrm{j}_{\mathrm{n}=1} 0_{2, \mathrm{n}} \leqq \sum_{\mathrm{n}=1}^{\mathrm{j}-1} 0_{1, \mathrm{n}}+\mathrm{x}_{1, \mathrm{j}} \leqq \sum_{\mathrm{n}=1}^{\mathrm{j}} 0_{2, \mathrm{n}}+\left[\mathrm{x}_{1, j}-\mathrm{x}_{2, \mathrm{j}}\right]^{+},
$$

the state $S_{j}\left(W_{1}, W_{2} \mid m\right)$ is occurred in

$$
\sum_{n=1}^{j-1-m} 0_{2, n} \leqq \sum_{n=1}^{j-1} 0_{1, n}+x_{1, j}<\sum_{n=1}^{j-m} 0_{2, n} \quad(0 \leqq m \leqq M-1),
$$

and the state $\mathrm{s}_{j}\left(\mathrm{~W}_{1}, \mathrm{~W}_{2} \mid \mathrm{M}\right)$ is occurred in

$$
\sum_{n=1}^{j-M} 0_{2, n}-\left[x_{2, j-M}-X_{1, j}\right]^{+} \leqq \sum_{n=1}^{j-1} 0_{1, n}+x_{1, j}<\sum_{n=1}^{j-M} 0_{2, n} .
$$

In Fig. 3.1 the above relations are described. 


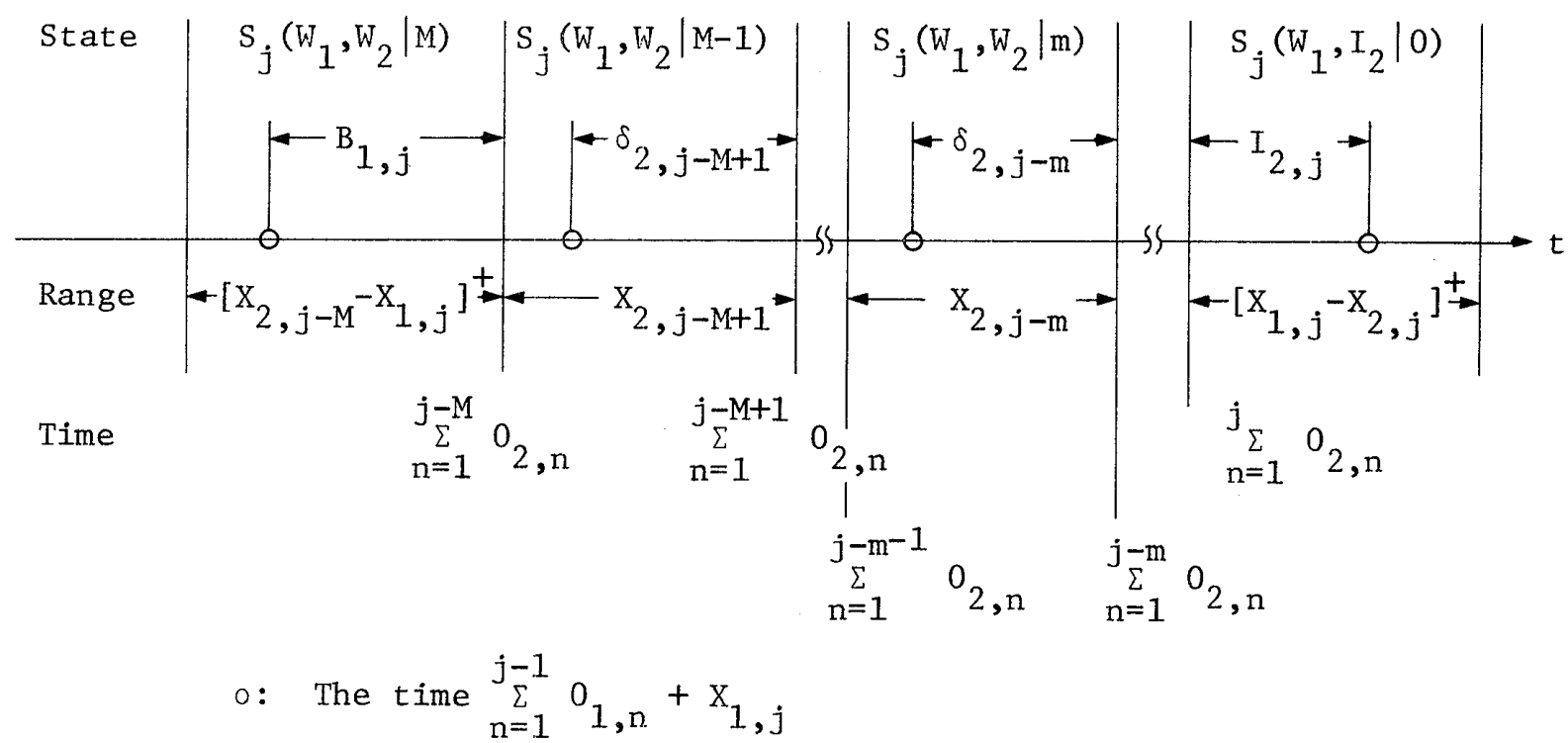

Fig. 3.2 The system state

In this figure $I_{2, j}, B_{1, j}$ and $\delta_{2, j-m}(0 \leqq m \leqq M-1)$ denote the idling time occurred immediately after the ejection of the $j$-th work in stage 2 , the blocking time occurred immediately after the completion of service for the $j$-th work in stage 1 and the rest part of service time for the $(j-m)-t h$ work which exists in stage 2 when the service for the $j$-th work in stage $I$ is completed and also there are $m$ in-process works in the buffer, and they are given by

$$
\begin{aligned}
& I_{2, j}=\left[\left(\sum_{n=1}^{j-1} 0_{1, n}+x_{1, j}\right)-\sum_{n=1}^{j} 0_{2, n}\right]^{+} \leqq\left[x_{1, j}-x_{2, j}\right]^{+} \\
& B_{1, j}=\left[\sum_{n=1}^{j-M} 0_{2, n}-\left(\sum_{n=1}^{j-1} 0_{1, n}+x_{1, j}\right)\right]^{+} \leq\left[x_{2, j-M}-x_{1, j}\right]^{+} \\
& \delta_{2, j-m}=\left[\sum_{n=1}^{j-m} 0_{2, n}-\left(\sum_{n=1}^{j-1} 0_{1, n}+x_{1, j}\right)\right]^{+}<x_{2, j-m} .
\end{aligned}
$$

In this model the system state at any time does not form the Markov chain but the state at $\sum_{n=1}^{j-1} 0_{1, n}+x_{1, j}-0$ forms the imbedded Markov chain, therefore this transition probabilities are determined by the number of works for which the services are completed in stage 2 during the service time $x_{1, j+1}$. In Table 3.1 the transition probabilities are represented. In this table $\delta_{2, j-m}$ is the unknown random variable, but the p.d.f. $h_{m}(\delta)$ can be calculated as follows.

We define the completed part of the service time $\Delta_{2, j-m}$ for the $(j-m)-t h$ work which exists in stage 2 when the $(j+1)$-th work in stage 1 is ejected, and denote the p.d.f. by $g_{m}(\Delta)$. Then $\Delta_{2, j-m}$ and $x_{2, j-m}$ are mutually independent and 
Table 3.1 Transition probability

\begin{tabular}{|c|c|c|}
\hline $\begin{array}{l}\text { State at } \\
\sum_{n=1}^{j-1} 0_{1, n}+x_{1, j}-0\end{array}$ & $\begin{array}{l}\text { State at } \\
j \\
\sum_{n=1} 00, n+X_{1, j+1}-0\end{array}$ & Transition Probability \\
\hline $\mathrm{s}_{j}\left(\mathrm{~W}_{1}, \mathrm{~W}_{2} \mid \mathrm{M}\right)$ & $\begin{array}{l}S_{j+1}\left(W_{1}, W_{2} \mid M\right) \\
S_{j+1}\left(W_{1}, W_{2} \mid m\right) \\
S_{j+1}\left(W_{1}, I_{2} \mid 0\right)\end{array}$ & $\begin{array}{l}\text { Prob. }\left(x_{1, j+1} \leqq x_{2, j+1-M}\right) \\
\text { Prob. }\left(\sum_{n=m+1}^{M} x_{2, j+1-n}<x_{1, j+1} \leqq \sum_{n=m}^{M} x_{2, j+1-n)}\right. \\
\text { Prob. }\left(\sum_{n=0}^{M} x_{2, j+1-n}<x_{1, j+1}\right)\end{array}$ \\
\hline $\mathrm{S}_{j}\left(\mathrm{~W}_{1}, \mathrm{~W}_{2} \mid \mathrm{m}\right)$ & $s_{j+1}\left(w_{1}, w_{2} \mid m+1\right)$ & Prob. $\left(x_{1, j+1} \leqq \delta_{2, j-m}\right)$ \\
\hline$(0 \leqq m \leqq M-1)$ & $s_{j+1}\left(W_{1}, w_{2} \mid m\right)$ & Prob. $\left(\delta_{2, j-m}<X_{1, j+1} \leqq \delta_{2, j-m}+X_{2, j-m+1}\right)$ \\
\hline$(0 \leqq k \leqq m-1)$ & $s_{j+1}\left(w_{1}, w_{2} \mid k\right)$ & 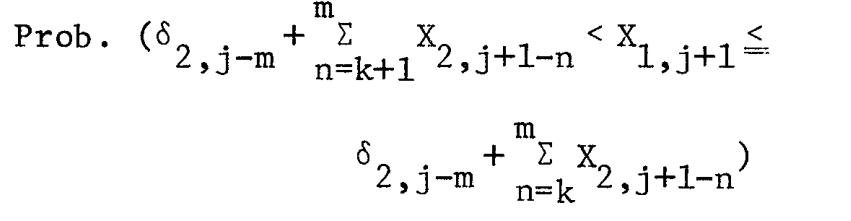 \\
\hline & $s_{j+1}\left(W_{1}, I_{2} \mid 0\right)$ & Prob. $\left(\delta_{2, j-m}+\sum_{n=0}^{m} x_{2, j+1-n}<x_{1, j+1}\right)$ \\
\hline$S_{j}\left(W_{1}, I_{2} \mid 0\right)$ & $\begin{array}{l}S_{j+1}\left(W_{1}, W_{2} \mid 0\right) \\
S_{j+1}\left(W_{1}, I_{2} \mid 0\right)\end{array}$ & $\begin{array}{l}\text { Prob. }\left(x_{1, j+1} \leqq x_{2, j+1}\right) \\
\text { Prob. }\left(x_{2, j+1}<x_{1, j+1}\right)\end{array}$ \\
\hline
\end{tabular}

$\delta_{2, j-m}$ is given by

$$
\delta_{2, j-m}=x_{2, j-m}-\Delta_{2, j-m},
$$

therefore $h_{m}(\delta)$ is represented by

$$
\begin{aligned}
h_{m}(\delta) & =\frac{\int_{0}^{\infty} g_{m}(\Delta) f_{2}(\Delta+\delta) d \Delta}{\int_{0}^{\infty} \int_{0}^{\infty} g_{m}(\Delta) f_{2}(\Delta+\delta) d \Delta d \delta} \\
& =\lambda_{2} \exp \left(-\lambda_{2} \delta\right),
\end{aligned}
$$


where the p.d.f. $f_{2}(x)$ of the service time in stage 2 is

$$
f_{2}(x)=\lambda_{2} \exp \left(-\lambda_{2} x\right)
$$

Consequently it is appeared that $\delta_{2, j-m}$ has the same p.d.f. with that of $x_{2, j-m}$ and all the transition probabilities can be calculated and finally we can estimate the system state probabilities in the steady state condition.

Now we estimate the steady state probabilities. These transition probabilities can be rewritten by $k_{i}$

$$
k_{i}=\int_{0}^{\infty} \frac{\left(\lambda_{2} x\right)^{i}}{i !} \exp \left(-\lambda_{2} x\right) f_{1}(x) d x
$$

and the system state equations in the steady state condition are given by

$$
\begin{aligned}
& P\left(W_{1}, W_{2} \mid M\right)=\left\{P\left(W_{1}, W_{2} \mid M\right)+P\left(W_{1}, W_{2} \mid M-1\right)\right\} k_{0} \\
& P\left(W_{1}, W_{2} \mid M-1\right)=\left\{P\left(W_{1}, W_{2} \mid M\right)+P\left(W_{1}, W_{2} \mid M-1\right)\right\} k_{1}+P\left(W_{1}, W_{2} \mid M-2\right) k_{0} \\
& P\left(W_{1}, W_{2} \mid M-2\right)=\left\{P\left(W_{1}, W_{2} \mid M\right)+P\left(W_{1}, W_{2} \mid M-1\right)\right\} k_{2}+P\left(W_{1}, W_{2} \mid M-2\right) k_{1} \\
& +P\left(\omega_{1}, W_{2} \mid M-3\right) k_{0} \\
& \begin{array}{c}
\vdots \\
\vdots \\
P\left(W_{1}, W_{2} \mid 0\right)=\left\{P\left(W_{1}, W_{2} \mid M\right)+P\left(W_{1}, W_{2} \mid M-1\right)\right\} k_{M}+P\left(W_{1}, W_{2} \mid M-2\right) k_{M-1}
\end{array} \\
& +\ldots \ldots \ldots+P\left(W_{1}, W_{2} \mid 0\right) k_{1}+P\left(W_{1}, I_{2} \mid 0\right) k_{0} \\
& P\left(W_{1}, I_{2} \mid 0\right)=\left\{P\left(W_{1}, W_{2} \mid M\right)+P\left(W_{1}, W_{2} \mid M-1\right)\right\} \sum_{i=M+1}^{\infty} k_{i}+P\left(W_{1}, W_{2} \mid M-2\right) \sum_{i=M}^{\infty} k_{i} \\
& +\ldots \ldots \ldots+P\left(W_{1}, W_{2} \mid 0\right) \sum_{i=2}^{\infty} k_{i}+P\left(W_{1}, I_{2} \mid 0\right) \sum_{i=1}^{\infty} k_{i}
\end{aligned}
$$

$\mathrm{P}(\cdot)$ : The steady state probability that the system state is $\mathrm{S}(\cdot)$.

Therefore, if $P_{i}$ denotes $P\left(W_{1}, W_{2} \mid M-i\right)$ and $P_{M+1}$ denotes $P\left(W_{1}, I_{2} \mid 0\right)$, these equations are rewritten by using $K(Z)$ and $F(Z)$ 


$$
\begin{aligned}
& \mathrm{K}(\mathrm{Z})=\sum_{i=0}^{\infty} k_{i} \mathrm{Z}^{i} \\
& \mathrm{~F}(\mathrm{z})=\sum_{i=0}^{\infty} \mathrm{P} i^{z^{i}}
\end{aligned}
$$

where $\mathrm{P}_{i}=0(i \geq M+2)$, and we have

$$
F(Z)=P_{0} \cdot \frac{1-Z}{1-Z / K(Z)}+Z^{M+2} H(Z),
$$

where $H(Z)$ is the power series of $Z$.

If the Laplace transform of $f_{1}(x)$ is represented by $U_{1}(s)$, we have

$$
K(Z)=U_{1}\left(\lambda_{2}(1-Z)\right)
$$

so the above equation is

$$
F(Z)=P_{0} \cdot \frac{1-Z}{1-Z / U_{1}\left(\lambda_{2}(1-Z)\right)}+Z^{M+2} H(Z) .
$$

In this equation the steady state probabilities $P_{i}(0 \leqq i \leqq M+1)$ are given by the coefficient of $\mathrm{Z}^{i}$ and expressed in terms of $\mathrm{P}_{0}$ if $\mathrm{U}_{1}(\cdot)$ can be expanded in a power series. Moreover the root of the equation $1-Z / U_{1}\left(\lambda_{2}(1-Z)\right)=0$ has always $Z=1$ and if we denote the other roots by $1 / \alpha_{i}$, the equation ( 3.7 ) is

$$
F(z)=P_{0} \cdot \frac{1}{\left(1-\alpha_{1} z\right)\left(1-\alpha_{2} z\right) \ldots \ldots \ldots}+z^{M+2} H(z) .
$$

4. Various 1 ine characters

First we estimate the idling time $I_{2, j+1}$ and the blocking time $B_{1, j+1}$. In this mode1 $B_{1, j+1}$ is occurred when the system state at $\sum_{n=1}^{j-1} 0_{1, n}+X_{1, j}-0$ is $S_{j}\left(W_{1}, W_{2} \mid M\right)$ and changes to $S_{j+1}\left(W_{1}, W_{2} \mid M\right)$ at $\sum_{n=1}^{j} 0_{1, n}+X_{1, j+1}-0$ or when the state is $S_{j}\left(W_{1}, W_{2} \mid M-1\right)$ and changes to $S_{j+1}\left(W_{1}, W_{2} \mid M\right)$, and it is not occurred in the other cases. Therefore $B_{1, j+1}$ is represented by

$$
\text { (4.1) } \quad \begin{aligned}
B_{1, j+1} & =\left[x_{2, j-M+1}-X_{1, j+1}\right]^{+} \text {or } \\
& =\left[\delta_{2, j-M+1}-X_{1, j+1}\right]^{+} \text {or } \\
& =0 .
\end{aligned}
$$

Consequently the p.d.f. $w_{B}(x)(x>0)$ for the blocking time $B_{1, j+1}$ is given by 


$$
\begin{aligned}
w_{B}(x)= & P_{j}\left(W_{1}, W_{2} \mid M\right) \cdot P_{T}\left[S_{j}\left(W_{1}, W_{2} \mid M\right) \rightarrow S_{j+1}\left(W_{1}, W_{2} \mid M\right)\right] . \\
& \frac{\bar{f}(x)}{\text { Prob. }\left(X_{2, j-M+1} \geq X_{1, j+1}\right)} \\
+ & P_{j}\left(W_{1}, W_{2} \mid M-1\right) \cdot P_{T}\left[S_{j}\left(W_{1}, W_{2} \mid M-1\right) \rightarrow S_{j+1}\left(W_{1}, W_{2} \mid M\right)\right] . \\
& \frac{\bar{f}(x)}{\text { Prob. }\left(\delta_{2, j-M+1} \geq X_{1, j+1}\right),}
\end{aligned}
$$

$P_{j}(\cdot)$ : The probability that the system state at $\sum_{n=1}^{j-1} 0_{1, n}+X_{1, j}-0$ is $s_{j}(\cdot)$ $\mathrm{P}_{\mathrm{T}}\left[\mathrm{S}_{\mathrm{j}}(\cdot) \rightarrow \mathrm{S}_{\mathrm{j}+1}(\cdot)\right]$ : The transition probability that the system state changes from $s_{j}(\cdot)$ to $s_{j+1}(\cdot)$

$\bar{f}(x): \quad \int_{0}^{\infty} f_{1}(y) f_{2}(y+x) d y$.

On the other hand $I_{2, j+1}$ is occurred when the system state at $\sum_{n=1}^{j-1} 0_{1, n}+X_{1, j}-0$ is $S_{j}\left(W_{1}, W_{2} \mid M\right)$ and changes to $S_{j+1}\left(W_{1}, I_{2} \mid 0\right)$ at $\sum_{n=1}^{j} 0_{1, n}+X_{1, j+1}-0$, when the state is $S_{j}\left(W_{1}, W_{2} \mid m\right)(0 \leqq m \leqq M-1)$ and changes to $S_{j+1}\left(W_{1}, I_{2} \mid 0\right)$ or when the state is $S_{j}\left(W_{1}, I_{2} \mid 0\right)$ and changes to $S_{j+1}\left(W_{1}, I_{2} \mid 0\right)$, and it is not occurred in the other cases. Therefore it is represented by

$$
\begin{aligned}
I_{2, j+1} & =\left[x_{1, j+1}-\sum_{n=0}^{M} X_{2, j+1-n}\right]^{+} \text {or } \\
& =\left[x_{1, j+1}-\delta_{2, j-m}-\sum_{n=0}^{m} x_{2, j+1-n}\right]^{+} \text {or } \\
& =\left[x_{1, j+1}-x_{2, j+1}\right]^{+} \text {or } \\
& =0 .
\end{aligned}
$$

Consequently the p.d.f. $w_{I}(x)(x>0)$ for the idling time $I_{2, j+1}$ is given by

$$
\begin{aligned}
W_{I}(x)= & P_{j}\left(W_{1}, W_{2} \mid M\right) \cdot P_{T}\left[S_{j}\left(W_{1}, W_{2} \mid M\right) \rightarrow S_{j+1}\left(W_{I}, I_{2} \mid 0\right)\right] . \\
& \frac{\bar{f}_{M+1}(x)}{\text { Prob. }\left(x_{1, j+1}>\sum_{n=0}^{M} X_{2, j+1-n}\right)} \\
& +\sum_{m=0}^{M-1} P_{j}\left(W_{1}, W_{2} \mid m\right) \cdot P_{T}\left[S_{j}\left(W_{1}, W_{2} \mid m\right) \rightarrow S_{j+1}\left(W_{1}, I_{2} \mid 0\right)\right] .
\end{aligned}
$$




$$
\begin{aligned}
& \text { Prob. } \frac{\bar{f}_{m+2}(x)}{\left(x_{1, j+1}>\delta_{2, j-m}+{ }_{n=0}^{m} x_{2, j+1-n}\right)} \\
& +P_{j}\left(W_{1}, I_{2} \mid 0\right) \cdot P_{T}\left[S_{j}\left(W_{1}, I_{2} \mid 0\right) \rightarrow S_{j+1}\left(W_{1}, I_{2} \mid 0\right)\right] . \\
& \text { Prob. } \frac{\bar{f}_{1}(x)}{\left(x_{1, j+1}>X_{2, j+1}\right),} \\
& \bar{f}_{m}(x): \int_{0}^{\infty} f_{2}{ }^{(m)}(y) f_{1}(y+x) d y,
\end{aligned}
$$

where $\mathrm{f}_{2}^{(\mathrm{m})}(\mathrm{x})$ denotes the $\mathrm{m}$ times convolution function of $\mathrm{f}_{2}(\mathrm{x})$. From the Table 3.1 we have the next equalities, too

$$
\begin{aligned}
& P_{T}\left[S_{j}\left(W_{1}, W_{2} \mid M\right) \rightarrow S_{j+1}\left(W_{1}, W_{2} \mid M\right)\right]=\text { Prob. }\left(X_{2, j-M+1} \geqq X_{1, j+1}\right) \\
& P_{T}\left[S_{j}\left(W_{1}, W_{2} \mid M-1\right) \rightarrow S_{j+1}\left(W_{1}, W_{2} \mid M\right)\right]=\text { Prob. }\left(\delta_{\left.2, j-M+1 ~ \geqq X_{1, j+1}\right)}\right. \\
& P_{T}\left[S_{j}\left(W_{1}, W_{2} \mid M\right) \rightarrow S_{j+1}\left(W_{1}, I_{2} \mid 0\right)\right]=\text { Prob. }\left(X_{1, j+1}>\sum_{n=0} X_{2, j+1-n}\right) \\
& P_{T}\left[S_{j}\left(W_{1}, W_{2} \mid m\right) \rightarrow S_{j+1}\left(W_{1}, I_{2} \mid 0\right)\right]=\text { Prob. }\left(X_{1, j+1}>\delta_{2, j-m}+\sum_{n=0} X_{2, j+1-n}\right) \\
& P_{T}\left[S_{j}\left(W_{1}, I_{2} \mid 0\right) \rightarrow S_{j+1}\left(W_{1}, I_{2} \mid 0\right)\right]=\text { Prob. }\left(X_{1, j+1}>X_{2, j+1}\right),
\end{aligned}
$$

so that in the steady state condition (4.2) and (4.4) are rewritten by

$$
\begin{aligned}
& \mathrm{w}_{B}(\mathrm{x})=\left(\mathrm{P}_{0}+\mathrm{P}_{1}\right) \cdot \overline{\mathrm{f}}(\mathrm{x}) \\
& \mathrm{w}_{I}(\mathrm{x})=\left(\mathrm{P}_{0}+\mathrm{P}_{1}\right) \cdot \overline{\mathrm{f}}_{M+1}(\mathrm{x})+\sum_{\mathrm{m}=2}^{M+1} \mathrm{P}_{\mathrm{m}} \cdot \overline{\mathrm{f}}_{M+2-\mathrm{m}}(\mathrm{x}) .
\end{aligned}
$$

In this model the efficiency $\rho$ is represented by

$$
\text { (4.7) } \rho=\frac{1}{\overline{\mathrm{X}}_{1}+\overline{\mathrm{B}}_{1}}=\frac{1}{\overline{\mathrm{x}}_{2}+\overline{\mathrm{I}}_{2}}
$$

where $\overline{\mathrm{X}}_{i}, \overline{\mathrm{B}}_{1}$ and $\overline{\mathrm{I}}_{2}$ denote the mean operation time in stage $i$, the mean blocking time in stage 1 and the mean idling time in stage 2. And the number of inprocess works distribution at the time just before the completion of service in stage 1 is given by $P_{i}(0 \leqq i \leq M+1)$ and the mean number $\bar{N}$ of the in-process works is given by 
(4.8) $\quad \overline{\mathrm{N}}=\sum_{\mathrm{m}=0}^{\mathrm{M}} \mathrm{m} \cdot \mathrm{P}\left(\mathrm{W}_{I}, \mathrm{~W}_{2} \mid \mathrm{m}\right)={ }_{\mathrm{m}=0}^{\mathrm{M}} \sum_{0} \mathrm{~m} \cdot \mathrm{P}_{\mathrm{M}-\mathrm{m}} \cdot$

5. The dual "model

In this section we discuss the dual model in which the service time in each stage is exchanged.

At first we consider the system states occurred at the time $t=\sum_{n=1}^{j} 0, n-0$, i.e. the time just before the ejection of the $j$-th work in stage 2 . These states are defined by

$\mathrm{S} \underset{\mathrm{j}}{*}\left(\mathrm{~W}_{1}, \mathrm{H}_{2} \mid \mathrm{m}\right)$ : Stages 1 and 2 are in operating and $\mathrm{m}$ in-process works are in the buffer $(0 \leqq m \leqq M)$

$\mathrm{S} \underset{j}{*}\left(B_{1}, W_{2} \mid M\right):$ Stage 1 is in blocking, Stage 2 is in operating and $M$ inprocess works are in the buffer,

and the relation between the system states and the range of time in which each state is occurred are described in Fig. 5.1. In this figure $I_{2}^{*}, j, B_{1}^{*}, j+M$ and $\delta * \underset{1, j+m}{*}(1 \leqq m \leqq M)$ denote the idling time occurred immediately after the ejection of the $j$-th work in stage 2 , the blocking time occurred immediately after the completion of service for the $(j+M)-$ th work in stage 1 and the rest part of service time for the $(j+m)$-th work which exists in stage 1 when the service for the $j$-th work in stage 2 is completed and also there are $\mathrm{m}$ in-process works in the buffer.

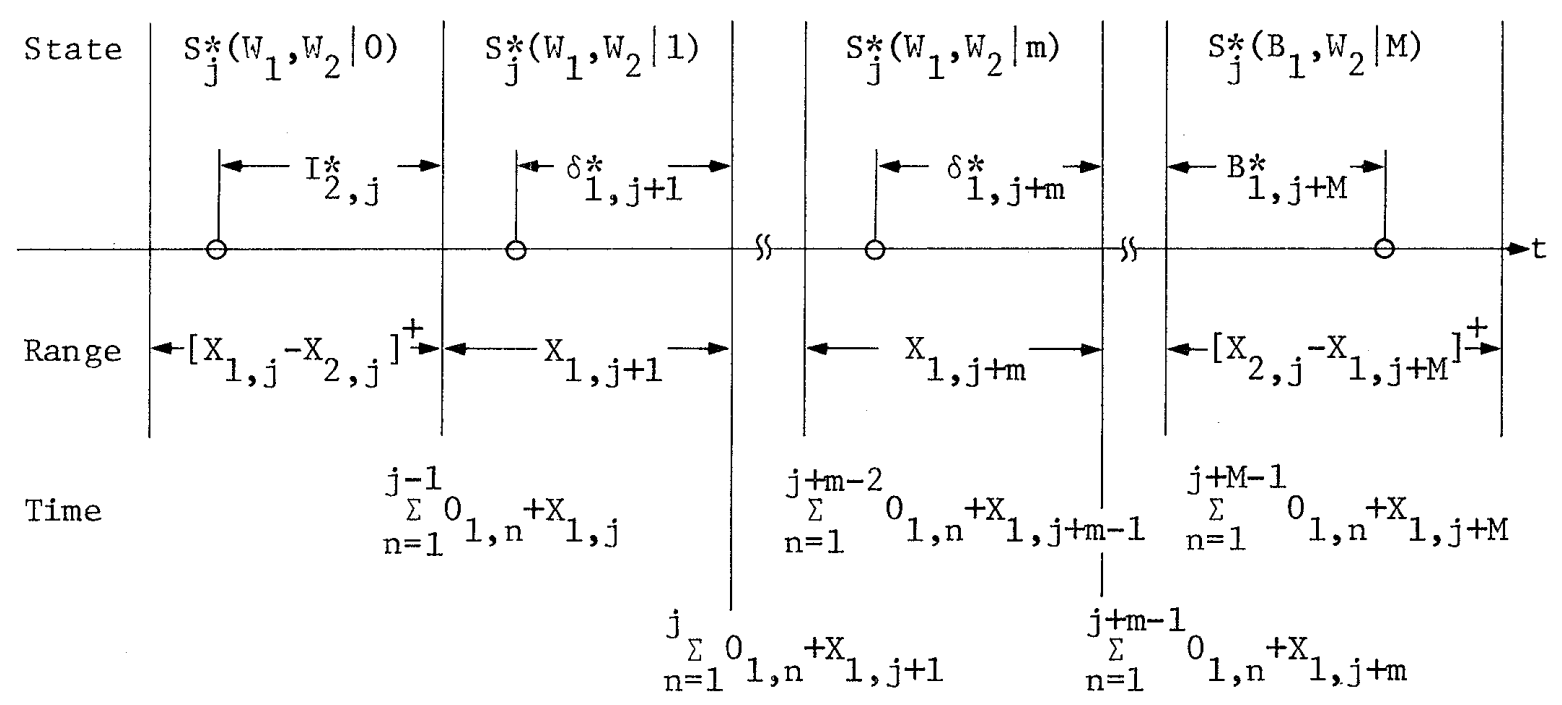

o: The time ${ }_{n=1}^{j} 0_{2, n}$

Fig. 5.1 The system state 
In this model the state at $\sum_{n=1}^{j} 0_{2, n}-0$ forms the imbedded Markov chain and these transition probabilities are determined by the number of works for which the services are completed in stage 1 during the service time $x_{2, j+1}$. In Table 5.1 these probabilities are represented, where $\delta_{1, j+m}^{*}$ has the same p.d.f. with the p.d.f. for the service time in stage 1 and it is represented by

$$
\mathrm{f} \underset{1}{*}(\mathrm{x})=\lambda_{1} \exp \left(-\lambda_{1} \mathrm{x}\right)
$$

Table 5.1 Transition probability

\begin{tabular}{|c|c|c|}
\hline $\begin{array}{l}\text { State at } \\
j_{\sum=1} 0, n\end{array}$ & $\begin{array}{l}\text { State at } \\
\mathrm{j}+100 \\
\mathrm{n}=1\end{array}$ & Transition Probability \\
\hline $\mathrm{S}_{j}^{*}\left(\mathrm{~W}_{1}, \mathrm{~W}_{2} \mid 0\right)$ & $\begin{array}{l}S_{j+1}^{*}\left(W_{1}, W_{2} \mid 0\right) \\
S_{j+1}^{*}\left(W_{1}, W_{2} \mid m\right) \\
S_{j+1}^{*}\left(B_{1}, W_{2} \mid M\right)\end{array}$ & $\begin{array}{l}\text { Prob. }\left(x_{2, j+1} \leqq x_{1, j+1}\right) \\
\text { Prob. }\left(\sum_{n=1}^{m} x_{1, j+n}<x_{2, j+1} \leqq \sum_{n=1}^{m+1} x_{1, j+n}\right) \\
\text { Prob. }\left(\sum_{n=1}^{M+1} x_{1, j+n}<x_{2, j+1}\right)\end{array}$ \\
\hline $\begin{array}{l}\mathrm{S}_{\mathrm{j}}^{*}\left(\mathrm{~W}_{1}, \mathrm{~W}_{2} \mid \mathrm{m}\right) \\
(1 \leq \mathrm{m} \leq \mathrm{M})\end{array}$ & $\begin{array}{l}S_{j+1}^{*}\left(W_{1}, W_{2} \mid m-1\right) \\
S_{j+1}^{*}\left(W_{1}, W_{2} \mid m\right)\end{array}$ & $\begin{array}{l}\text { Prob. }\left(x_{2, j+1} \leqq \delta_{1, j+m}^{*}\right) \\
\text { Prob. }\left(\delta_{1, j+m}^{*}<x_{2, j+1} \leqq \delta_{1, j+m}^{*}+x_{1, j+m+1}\right)\end{array}$ \\
\hline$(m+1 \leqq k \leqq M)$ & $S_{j+1}^{*}\left(W_{1}, W_{2} \mid k\right)$ & $\begin{array}{r}\text { Prob. ( } \delta_{1, j+m}^{*}+\sum_{n=m+1}^{k} x_{1, j+n}<x_{2, j+1} \leqq \\
\left.\delta_{1, j+m}^{*}+\sum_{n=m+1}^{k} x_{1, j+n}\right)\end{array}$ \\
\hline$S *\left(B_{1}, W_{2} \mid M\right)$ & $\begin{array}{l}S_{j+1}^{*}\left(B_{1}, W_{2} \mid M\right) \\
S_{j+1}^{*}\left(W_{1}, W_{2} \mid M\right) \\
S_{j+1}^{*}\left(B_{1}, W_{2} \mid M\right)\end{array}$ & $\begin{array}{l}\text { Prob. }\left(\delta_{1, j+m}^{*}+\sum_{n=m+1}^{M+1} x_{1, j+n}<x_{2, j+1}\right) \\
\text { Prob. }\left(x_{2, j+1} \leqq X_{1, j+M+1}\right) \\
\text { Prob. }\left(x_{1, j+M+1}<X_{2, j+1}\right)\end{array}$ \\
\hline
\end{tabular}


From this Table we can estimate the steady state probabilities $\mathrm{P} *\left(\mathrm{~W}_{1}, \mathrm{~W}_{2} \mid \mathrm{m}\right)$ and $\mathrm{P} *\left(\mathrm{~B}_{1}, \mathrm{~W}_{2} \mid \mathrm{M}\right)$, and if we denote

$$
\begin{aligned}
& P_{i}^{*}=P *\left(W_{1}, W_{2} \mid i\right) \quad(0 \leqq i \leqq M) \\
& P_{M+1}^{*}=P *\left(B_{1}, W_{2} \mid M\right)
\end{aligned}
$$

and

$$
F *(Z)=\sum_{i=0}^{\infty} P * Z^{i}
$$

we have the following system equation, where $P \underset{i}{*}=0(i \geq M+2)$,

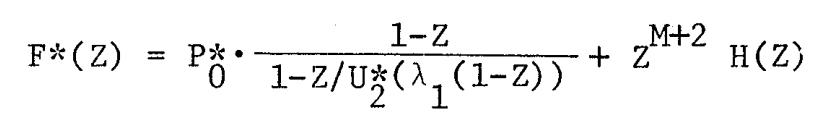

$\mathrm{U}_{2}^{*}(\mathrm{~s})$ : Laplace transform in terms of $\mathrm{f}_{2}^{*}(\mathrm{x})$.

In the dual models we have

$$
\begin{aligned}
& \mathrm{U}_{2}^{*}\left(\lambda_{1}(1-\mathrm{Z})\right)=\mathrm{U}_{1}\left(\lambda_{2}(1-\mathrm{Z})\right) \\
& \lambda_{1}=\lambda_{2},
\end{aligned}
$$

so the following equalities are obtained

$$
\text { (5.5) } \quad \mathrm{P}_{i}^{*}=\mathrm{P}_{i}
$$

and

$$
\begin{aligned}
& P *\left(W_{1}, W_{2} \mid m\right)=P\left(W_{1}, W_{2} \mid M-m\right) \quad(0 \leqq m \leqq M) \\
& P *\left(B_{1}, W_{2} \mid M\right)=P\left(W_{1}, I_{2} \mid 0\right) .
\end{aligned}
$$

The idling time $I_{2, j+1}^{*}$ and the blocking time $B_{1, j+M+1}^{*}$ are estimated by using the system state at $\sum_{n=1}^{j} 0_{2}, n^{-0}$ as follows. The idling time is occurred when the system state is $\mathrm{S}_{j}^{*}\left(\mathrm{~W}_{1}, \mathrm{~W}_{2} \mid 0\right)$ and changes to $\mathrm{S}_{j+1}^{*}\left(\mathrm{~W}_{1}, \mathrm{~W}_{2} \mid 0\right)$ or when the system state is $\mathrm{S}_{j}^{*}\left(\mathrm{~W}_{1}, \mathrm{~W}_{2} \mid 1\right)$ and changes to $\mathrm{S}_{j+1}^{*}\left(\mathrm{~W}_{1}, \mathrm{~W}_{2} \mid 0\right)$, and it is not occurred in the other cases. Therefore $I_{2, j+1}^{*}$ is represented by 


$$
\begin{aligned}
I_{2, j+1}^{*} & =\left[X_{1, j+1}-X_{2, j+1}\right]^{+} \text {or } \\
& =\left[\delta \frac{*}{1, j+1}-X_{2, j+1}\right]^{+} \text {or } \\
& =0 .
\end{aligned}
$$

And the blocking time $B_{1}^{*}, j+M+1$ is occurred when the system state is $S_{j}^{*}\left(W_{1}, W_{2} \mid 0\right)$ and changes to $S_{j+1}^{*}\left(B_{1}, W_{2} \mid M\right)$, when the state is $S_{j}^{*}\left(W_{1}, W_{2} \mid m\right)(1 \leqq m \leq M)$ and changes to $S_{j+1}^{*}\left(B_{1}, W_{2} \mid M\right)$ or when the state is $S_{j}^{*}\left(B_{1}, W_{2} \mid M\right)$ and changes to $S_{j+1}^{*}\left(B_{1}, W_{2} \mid M\right)$, and $i t$ is not occurred in the other cases, therefore it is represented by

$$
\begin{aligned}
B_{1, j+M+1}^{*} & =\left[X_{2, j+1}-\sum_{n=1}^{M+1} X_{1, j+n}\right]^{+} \text {or } \\
& =[x_{2, j+1}-\delta \underbrace{*}_{1, j+m}-\sum_{n=m+1}^{M+1} x_{1, j+n}]^{+} \text {or } \\
& =\left[x_{2, j+1}-X_{1, j+M+1}\right]^{+} \text {or } \\
& =0 .
\end{aligned}
$$

Therefore by using the same procedure in Section 4 the idling time distribution $w_{I}^{*}(x)(x>0)$ and the blocking time distribution $w_{B}^{*}(x)(x>0)$ in the steady state condition are given by

$$
\begin{aligned}
& W_{I}^{*}(x)=\left(P_{0}^{*}+P_{1}^{*}\right) \cdot \bar{f} *(x) \\
& W_{B}^{*}(x)=\left(P_{0}^{*}+P_{1}^{*}\right) \cdot \bar{f}_{M+1}^{*}(x)+\sum_{m=2}^{M+1} P_{m}^{*} \cdot \bar{f}_{M+2-m}^{*}(x), \\
& \bar{f} *(x): \quad \int_{0}^{\infty} f_{2}^{*}(y) f_{1}^{*}(y+x) d y \\
& \bar{f}_{m}^{*}(x): \quad \int_{0}^{\infty} f_{1}^{*}(m)(y) f_{2}^{*}(y+x) d y
\end{aligned}
$$

where $\mathrm{f}_{1}^{k^{(\mathrm{m})}}(\mathrm{x})$ denotes the $\mathrm{m}$ times convolution function of $\mathrm{f}_{1}^{*}(\mathrm{x})$. From $(4.6)$, (5.5) and (5.9) we have the following equalities,

$$
\begin{aligned}
& w_{I}^{*}(x)=w_{B}(x) \\
& w_{B}^{*}(x)=w_{I}(x) .
\end{aligned}
$$

Finally the mean number $\overline{\mathrm{N}} *$ of the in-process works is represented by (5.11) $\quad \overline{\mathrm{N}} *=\sum_{\mathrm{m}=0}^{\mathrm{M} m} \mathrm{~m} \cdot \mathrm{P} *\left(\mathrm{~W}_{1}, \mathrm{~W}_{2} \mid \mathrm{m}\right)+\mathrm{M} \cdot \mathrm{P} *\left(\mathrm{~B}_{1}, \mathrm{~W}_{2} \mid \mathrm{M}\right)$ 
and from $(4.8),(5.6)$ and $(5.11)$ we have

(5.12) $\quad \overline{\mathrm{N}} *=\mathrm{M}-\overline{\mathrm{N}}$.

\section{Conclusion}

We have discussed the procedure to estimate the effects of the design factors in the two-stage series lines in which the first stage has the arbitrary service time. And the various line characters are obtained and the relations between the dual models are presented. For example, we represent the mean idling times for the various two-stage series lines in Table 6.1 and 2 .

Table 6.1 Numerical results of $\bar{B}_{1}$ for the balancing line $\left(\lambda_{2}=1.0\right)$

\begin{tabular}{|c|cccc|c|c|}
\hline \multirow{2}{*}{$\mathrm{M}$} & \multicolumn{6}{|c|}{ Service Time Distribution $\mathrm{f}_{1}(\mathrm{x})$} \\
\cline { 2 - 7 } & $\mathrm{K}=1$ & $\mathrm{~K}=2$ & $\mathrm{~K}=4$ & $\mathrm{~K}=5$ & $\begin{array}{c}\text { Uniform } \\
0.5 \leq \mathrm{x} \leq 1.5\end{array}$ & $\begin{array}{c}\text { Constant } \\
\mathrm{x}=1.0\end{array}$ \\
\hline 0 & 0.5000 & 0.4444 & 0.4096 & 0.4019 & 0.3834 & 0.3679 \\
1 & 0.3333 & 0.2807 & 0.2497 & 0.2428 & 0.2268 & 0.2141 \\
2 & 0.2500 & 0.2045 & 0.1785 & 0.1731 & 0.1600 & 0.1500 \\
3 & 0.2000 & 0.1607 & 0.1389 & 0.1343 & 0.1235 & 0.1154 \\
4 & 0.1667 & 0.1324 & 0.1136 & 0.1098 & 0.1006 & 0.0938 \\
5 & 0.1429 & 0.1125 & 0.0962 & 0.0928 & 0.0848 & 0.0790 \\
6 & 0.1250 & 0.0978 & 0.0833 & 0.0804 & 0.0734 & 0.0682 \\
7 & 0.1111 & 0.0865 & 0.0735 & 0.0709 & 0.0646 & 0.0600 \\
8 & 0.1000 & 0.0776 & 0.0658 & 0.0634 & 0.0577 & 0.0536 \\
\hline
\end{tabular}


Table 6.2 Numerical results of $\bar{B}_{1}$ for the unbalancing 1ine $\left(\lambda_{1}=0.5, \lambda_{2}=1.0\right)$

\begin{tabular}{|c|cccc|c|c|}
\hline \multirow{2}{*}{$\mathrm{M}$} & \multicolumn{6}{|c|}{ Service Time Distribution $\mathrm{f}_{1}(\mathrm{x})$} \\
\cline { 2 - 7 } & $\mathrm{K}=1$ & $\mathrm{~K}=2$ & $\mathrm{~K}=4$ & $\mathrm{~K}=5$ & $\begin{array}{c}\text { Uniform } \\
1.0 \leq \mathrm{E} \leq \mathrm{x} \leq 3.0\end{array}$ & $\begin{array}{c}\text { Constant } \\
\mathrm{x}=2.0\end{array}$ \\
\hline 0 & 0.3333 & 0.2500 & 0.1975 & 0.1859 & 0.1590 & 0.1353 \\
1 & 0.1429 & 0.0833 & 0.0530 & 0.0471 & 0.0346 & 0.0251 \\
2 & 0.0667 & 0.0303 & 0.0154 & 0.0129 & 0.0081 & 0.0050 \\
3 & 0.0323 & 0.0114 & 0.0046 & 0.0036 & 0.0019 & 0.0010 \\
4 & 0.0159 & 0.0043 & 0.0014 & 0.0010 & 0.0005 & 0.0002 \\
5 & 0.0079 & 0.0016 & 0.0004 & 0.0003 & 0.0001 & \\
6 & 0.0039 & 0.0006 & 0.0001 & 0.0001 & & \\
7 & 0.0020 & 0.0002 & & & & \\
8 & 0.0010 & 0.0001 & & & & \\
\hline
\end{tabular}

$\lambda_{i}:$ The operation rate in stage $i$

\section{Acknowledgement}

The author sincerely thanks Dr. K. Sato, Assistant Prof. T. Teshima and Dr. R. Setoguchi of Tohoku University for their helpful advices and the referees for their valuable comments.

Toshirou IYAMA

Department of Mechanical Engineering

II, Faculty of Engineering, Iwate

University, 4-3-5, Ueda, Morioka,

020, Japan 


\section{References}

[1] Anderson, D.R. and Moodie, C.L., "Optimal Buffer Storage Capacity in Production Line System," International Journal of Production Research, 7, 3 (1969), 233-240.

[2] Avi-Itzhak, B., "A Sequence of Service Stations with Arbitrary Input and Regular Service Times," Management Science, 11, 5 (1965), 565-571.

[3] Barten, K.A., "A Queueing Simulator for Determining Optimu Inventory Levels in a Sequential Process," Journal of Industrial Engineering, 3, 4 (1962), 245-252.

[4] Finch, P.D., "The Effect of the Size of the Waiting Room on a Simple Queue," Journal of the Royal Statistical Society, B, 20 (1958), 182-186.

[5] Hashida, 0., "On the Busy Period in the Queueing System with Finite Capacity," Journal of the Operations Research Society of Japan, 15, 3 (1972), 115-137.

[6] Hillier, F.S. and Boling, R.W., "The Effects of Some Design Factors on the Efficiency of Production Lines with Variable Operation Times," Journal of Industrial Engineering, 17, 12 (1966), 651-658.

[7] Hillier, F.S. and Boling, R.W., "Finite Queues in Series with Exponential or Erlang Semice Times - A Numerical Approach," Operations Research, 15, 2 (1967), 286-303.

[8] Hunt, G.C., "Sequential Arrays of Waiting Lines," Operations Research 4, 6 (1956), 674-683.

[9] Keilson, J., "The Ergodic Queue Length Distribution for Queueing Systems with Finite Capacity," Journal of the Royal Statistical Society, B, 28 (1966), 190-201.

[10] Knott, A.D., "The Inefficiency of a Series of Work Stations - a Simple FormuZa" International Journal of Production Research, 8, 2 (1970), 109-119.

[11] Makino, T., "On the Mean Passage Time concerning Some Queueing Problems of the Tandem Type," Journal of the Operations Research Society of Japan, 7, 1 (1964), 17-47.

[12] Makino, T., "On a Study of Output Distribution," Journal of the Operations Research Society of Japan, 8, 3 (1966), 109-133.

[13] Suzuki, T., "On a Tandem Queue with Blocking," Journal of the Operations Research Society of Japan, 6, 3 (1964), 137-157. 


\section{2 工程直列型生産ラインの効率}

，有限Buffer 容量を持つ2工程直列型生産ラインに関しては多くの研究があるが，工程の作業時間 が任意分布を持つ場合に対しては，その設計因子のライン特性に与える影響が十分議論されていない。 そこで本研究は，第一工程が任意の作業時間分布を持つ 2 工程直列型生産ラインの設計向が種々 のライン特性 (効率, Idling 時間分布, Blocking 時間分布さらに Buffer 内仕掛品数分布) に与え る影響を解析する方法を示し，さらに考えているモデルとその双対モデルの関係を明らかにし，一方 のモデルの結果からその双対モデルのライン特性が得られることを示す。

この方法は，工程 1 亿扣ける個々の製品の作業完了直前のライン状態が隄れマルコフ連鎖となって いる点に着目したもので, この状態推移から Idling や Blocking 時間の発生状況が明らかにされそ の分布が求められる。又, 双対モデルに対しても同様の方法を用いて解析し, 双対モデル間では効率 が等しく，一方のIdling 時間分布と他方の B locking 時間分布が同一でしかも互いのBuffer 内仕掛 品数の平均の和がBuffer 容量と等しくなることが示される。 